\title{
THE REFORM OF THE LOCAL SELF-GOVERNMENT \\ OF THE CZECH REPUBLIC AND SLOVENIA. EXPERIENCE FOR UKRAINE
}

\section{Murzina Tetiana ${ }^{1}$ \\ Pakhomova Tetiana ${ }^{2}$}

DOI: http://dx.doi.org/10.30525/978-9934-571-29-9_8

Abstract. The analysis of the main changes in the system of local self-government of Slovenia and the Czech Republic (in legislation and structure): the traditions of local self-government and its national peculiarities have been studied, the normative-legal base of local self-government has been analyzed in terms of the principle of subsidiarity in Slovenia and the Czech Republic at the settlement level (village, community) in accordance with the legislation of the European Union.

The reasons, conditions and consequences of local self-government reform are considered, attention is focused on changes in the territorial structure, distribution of powers between central and local authorities, legislative regulation, etc. The goals and objectives of the research are determined. Taking into account the similarity of the historical development of these countries with Ukraine, an attempt was made to analyze the process of solving problems that arose in them during the reform of the system of local self-government. The analysis of the current legislation on local self-government in the Czech Republic and Slovenia makes it possible to identify the strengths and weaknesses of the country and make appropriate conclusions in order to avoid such mistakes in the future.

Modern understanding of the legal provision of public administration involves the functioning of a universal organizational and legal mechanism for identifying, coordinating and implementing social needs and interests based on the use of various legal means, the formation of subjective rights

\footnotetext{
${ }^{1}$ Postgraduate Student of the Department of Regional Policy and Public Administration, Odessa Regional Institute for Public Administration of the National Academy for Public Administration under the President of Ukraine

${ }^{2}$ Head of the Department of Regional Policy and Public Administration,

Odessa Regional Institute for Public Administration

of the National Academy for Public Administration under the President of Ukraine
} 
and obligations of participants in social processes, the transfer of their relationships and relationships in specific legal relationship.

The experience of foreign countries suggests the existence of several approaches to the organization of self-government - depending on its relationship with the state authorities and the scope of its powers

Despite the large number of works on the issue of reforming local self-government, the current state of the system of local self-government in Ukraine and attempts to reform it have led to the search for new approaches to the territorial organization of power.

At the same time, the experience of European countries, in particular the former countries of the "socialist camp", which has also gone through the path of not only social change, but even the collapse of the countries, remains inadequately studied in the science of state administration. In this case, taking into account their experience and the ability to make correct conclusions in time becomes especially valuable for Ukraine.

This article describes the peculiarities of the processes of decentralization of power in the Czech Republic and Slovenia, in particular the financial independence of local self-government, a peculiar system of representation of the state at the lower level of government, the role of municipal institutions, etc. The main problems faced by Ukraine in the initiated reform of the decentralization of power are highlighted, and further directions of development of this process are outlined taking into account the experience of the mentioned countries.

\section{Introduction}

In the modern European civilization tradition, it is considered that local self-government is one of the main foundations of any democratic system. This thesis is enshrined in the European Charter of Local Self-Government, and Ukraine is included among the signatories of it.

Since the second half of the 20th century, in the states of Eastern and Southern Europe, at least twice, all the spheres of public life have been changed, including the reforms in the field of state building, in particular in the system of public authorities. An important place among them took the reorganization of local power, which was primarily connected with the rejection of the institution of local self-government in the so-called socialist period, and then with the revival of this institution after the change of political regimes in former countries of "people's democracy" at the end of the XX century. 
Local self-government and local administration in the post-socialist states of Eastern and Southern Europe are inextricably linked with the process of establishing of democratic regimes and, as a consequence, the formation of a new legislative framework that governs the activities of municipal institutions.

Within the framework of the European integration course, the reform of the basic organization of the population, which has entered the newest history of Ukraine as decentralization, is one of the most significant. It is clear that the existing model inherited from the Soviet era has largely lost its functionality. And since overcoming the lag in the development of democratic institutions of Ukraine is necessary to be done in the shortest possible time, the experience of more successful countries seems simply indispensable.

Thus, the study of the problem of the transition of Eastern European countries from the centralized system of public administration to local self-government becomes of special interest and urgency.

The purpose of the article is to conduct a theoretical and legal analysis of a complex of problems associated with the transition from a centralized system of public administration to the local level until the formation of local self-government and local administration in the states of Eastern and Southern Europe, as well as (taking into account the theoretical and practical results that already exist) detection and analysis of the features of the models of local self-government in the countries under study.

\section{Presentation of the main material}

In all democratic states, the presence of local authorities, endowed with a certain autonomy, is the realization of the principle of separation of powers in practice and, importantly, one of the main signs of pluralism in society. Destruction of local self-government is seen as a symptom of totalitarianism. In other words, the less power on the ground - the less democracy and the higher is the level of authoritarianism. (It was no accident that in the 1930s in Germany local self-government bodies became one of the first victims of the Nazi regime).

It should be noted that for the system of local self-government in the modern period of development, unlike businesses, the state of imbalance is provoked primarily by the processes occurring in the environment. To understand the behavior of such system is necessary to possess information about the 
composition "of the original system and the environment", the components of which are linked. As you know, any system evolving through the innovations (in our case, the system of local self-government) has the sufficient time and space in which its functioning and development occurs.

The systems, that are being developed, are characterized by a combination of stability and instability of the structure, because of the two stationary stable states of the system sustainable at any given time there can be the only one. For the system of local self-government (as for an adaptive social system) information characteristics that reflect semantic and pragmatic aspects of information become important. The principle of increasing of the adaptability of the local government system to dynamic external environment involves the implementation of such innovations that provide an increased adaptability of the system.

The European Charter of Local Self-Government was adopted in 1985 by the Congress of Local and Regional Authorities of the Council of Europe and is the most important multilateral document defining the fundamental principles of the functioning of local self-government bodies. The charter was signed by 47 states of Europe, including Ukraine.

In accordance with the European Charter, local self-government is based on three basic principles:

- the right to local self-government;

- power of general competence;

- the principle of subsidiarity [2, p. 295].

The right to local self-government is the consolidation this right at the level of laws and constitutions.

Power of general competence or general authority has the ability for local governments to take any actions, except those that are prohibited by national law.

In most Western European countries, local authorities have general competence, that is, the right to take any action in the interests of the local community, which is not specifically for them.

The principle of subsidiarity means that the competence in one or another area of activity, if possible, belongs to the lowest level of management that is as close as possible to the people. In other words, what can be solved by a village or settlement should not be decided at the district level. What can be solved at the district level should not be decided at the region level. And, accordingly, what can be solved at the level of the region should 
not be decided at the state level. Independent Ukraine inherited the Soviet-era management principles when central authorities attempted to include as many issues as possible in their area of competence, leaving to the communities only meaningless ones.

One of the directions of the reforms of the system of local self-government in Ukraine is decentralization. Decentralization is considered as the transfer of significant powers and budgets from the executive authorities to the local authorities. Decentralization is one of the types of the reforms that conduce to the progressive development of the country. Poland, Slovakia, Lithuania, Latvia, Estonia, Scandinavian countries - all of them went through such reform that gave impulse to the economy, social development of these countries.

The efficiency of the reforms of local self-government is closely linked with the adequacy of their scientific support. This increases the results of organic interaction between bodies of local self-governments and public institutions, business structures, scientific and educational institutions and others. The importance and necessity of the research of the problem of reforming the system of local self-government in the context of the innovation discourse is due to that this scientific problem has not found its system reflection in national and foreign scientific literature, has not become the object of close attention from the local authorities, politicians and the public. At the same time, it is clear that the qualitative analysis of the current position of the reforming of local self-government on the basis of innovating development will contribute to the effectiveness of the practical implementation of local self-government reform in Ukraine.

However, despite the importance of the development of scientific approaches to the processes of the reforming of the system of local self-government, a number of issues, associated with the analysis of the processes of reforms in the context of the innovative development, remains outside the attention of the scientists.

Let's consider the experience of some post-socialist republics.

\section{The Republic of Slovenia}

In accordance with the Slovenian constitution, local self-government is implemented in communities and other local organizations and associations.

The Slovenian Constitution contains corresponding norms both in the sections of general norms and in the sections of organization of local 
self-government (Slovenian Constitution of 23.12.1991 (Part 1. "Introduction" and Part V. "Self-government"). Slovenes carry out local self-government with the help of municipalities and others local self-government organizations (Article 138 of the Constitution of the Republic of Slovenia).

Communities form the main unit of local self-government, covering from one to several settlements. The territory communities are formed on the basis of referendum results that are held among residents of a particular locality. The consultative referendum on June 22, 2008 was devoted to the community association in the region [5].

There are 210 communities in the country, 11 of which have urban status. Within the limits of its competence the community independently decides on issues of local importance. Communities are self-financing at the expense of their own sources of income, and those who lack the funds receive additional financial subsidies from the state budget.

The highest governing body of the community is the Council, whose members are elected by direct vote. The head (zhupan) - the head of administration, is also elected by the people and controls the implementation of the decisions taken by the Council.

Communities were formed in Slovenia on the operational decisions, if the people in a certain area decided (and the authorities developed a procedure for each decision) to organize self-government, a local community or a municipality, the parliament, for the most part, adopted such decisions and passed the necessary law. For the formation of the communities, such criteria as the level of housing stock, the number of people, schools, kindergartens, some other existing institutions necessary for the functioning of the local community, were put forward, but there are many exceptions. Thus, in mountainous regions there are communities with a population of 500 people, not 5000 . That is, they are much smaller. The key criterion was the decision of the people who lived in the area.

Major statistical data:

The area of the country is 20,256 square kilometers; The population is 1,994,084 (as of December 1, 1992).

The Slovenes exercise authority and functions of local self-government through the self-governing municipalities and other local government organizations. A municipality may include one community or several. The municipality is founded on the basis of the law as a result of a positive vote in the referendum. A town or a city can get the status of a city municipality. 
The list of duties and functions of the municipality includes such local affairs, which concern only the population of this municipality.

The state may, by legislative procedure, impose certain duties and functions that fall within its jurisdiction over the municipalities. The state supervises the proper and effective fulfillment of all the duties and functions transferred to its municipalities. The supervision of the implementation of local government bodies is carried out by the specially created state bodies.

The system of local self-government is one of the most important norms of the Slovenian Constitution, which introduced new laws in this area. Shortly after the adoption of the Constitution in December 1991, there was a need to reform the structure of local self-government.

The current reform of local self-government has several changes on its aim. First of all, we need the territorial redistribution of communities. Today, the territory of the communities is large. Reducing communities is necessary in order to better meet the needs of citizens. According to the Constitution, territorial changes in the communities are adopted by referendum. Another reform that affects the system of local government is the reform of the structure of the state administration at the subregional level. The current structure of the state administration does not include general sub-government bodies for the performance of government functions at the local level. The reason for this decision is that today almost all tasks and competences of the state administration are concentrated at the local level in the administrative systems of local authorities. The proposed reform stems from the idea of a clear division of functions between the state administration and local governments.

There is no general government territorial division in Slovenia. There are only ministries that cover the entire territory of Slovenia and can carry out a variety of activities through their territorial services. The ministries set up such services where they must perform their respective tasks at the local level. Most government functions are carried out by communities and their administrative departments. Each ministry has its own representation at the local level, and such representations form a peculiar, partly hierarchical administrative structure.

The municipality may, according to the law, own, purchase and possess all types of property, establish public and other companies, and manage them, as well as determine their budget within the framework of the public finance system. 
The municipality's responsibilities include air, land and water protection, noise protection, waste collection and recycling.

Other responsibilities and functions:

- promotion of sports development;

- local events monitoring;

- organization of municipal services of the local police.

The municipality guarantees the fulfillment of local public tasks, defined by itself, as well as public tasks determined by law. Public services are governed by the laws regulating the supply and distribution of energy, transport and communication, water management with the enterprises concerned, and the protection of the environment.

Public authorities supervise the legality of actions of municipal authorities. State supervision of the work of local community bodies is exercised by the government of those ministries. The mayor must immediately submit to the government or the relevant ministry the decrees by which the municipality will regulate cases transferred to it from under state jurisdiction. The government or the ministry may suspend the enforcement of the decree that they consider to be illegal, as well as pass it on to the Constitutional Court.

Mandatory forms of interaction between local governments do not exist. But according to the Law on Local Self-Government, local communities can cooperate. Self-governing local community is a public entity.

Today, according to many experts, self-government is at a satisfactory level, since this institution has been functioning effectively in Slovenia for about a century.

But we see that Slovenia is not the best example here; it is still a very centralized state, like Ukraine.

\section{The local government of the Czech Republic}

The constitutional and legal foundations of the local self-government of the Czech Republic are laid down in Chap. 7 of the Constitution of the "Local Self-Government" and the laws "On the bribery (protest proceedings)" - the municipalities and "On the provinces (district proceedings)" the districts [10, p. 100].

According to Art. 8 of the Basic Law of the Czech Republic the principle of the local self-government of territorial units is guaranteed. This constitutional provision is one of the main principles of state-building in the Czech Republic [8]. 
The Czech Constitution, by establishing the scope of the right to local self-government, defined its basic principles:

- guarantee of the right to self-government (Article 101, paragraph 4).

- Self-government is an independent form of public authority with its own competence in the sphere of property, financial management, organization, rule-making (Article 101, point 1.2, Article 104 of the Constitution of the Czech Republic).

- The main carriers of the right to local self-government are the territorial communities of the citizens (Article 100, paragraph 1, Article 101 of the Constitution of the Czech Republic).

- The territorial basis of local self-government is the community (Article 99 of Article 100 of the Constitution of the Czech Republic).

- The presence of a representative body of local self-government is mandatory in the formation of the organizational structure of a specific municipal entity (Article 101, paragraph 1.2, Article 102, Article 104 of the Constitution of the Czech Republic) [8; 5, p. 176-177].

It is important to note that the Czech Constitution provides for the right to self-government as a right, and not the responsibility of the relevant municipal organizations. At the same time, according to Art. 101 of the Czech Constitution, the local self-government unit is characterized as "a public corporation that can own property and manage it according to its own budget." This concept is then elaborated in clause 2 of the ch. 2 of the Law "On the Circumcision" [8; 9].

The administrative-territorial reform in the Czech Republic was carried out in two stages and lasted for about 10 years. The first stage was aimed at developing the conceptual foundations for reform, in particular the preparation and approval of the Concept of Public Administration Reform.

First of all, the reform concerned the changes in the structure of the administrative-territorial division and the extension of the powers of local self-government bodies at the basic level. So, in 1990, the Czech Republic abandoned the three-level structure of the administrative-territorial system (municipality, district, region), introduced in 1960, and returned to a twolevel structure (municipality, province).

The liquidation of the regional committees has led to a sharp increase of the role of the central authorities and at the same time to reducing the effectiveness of public administration, depending on the size of the territory. The oblast was recognized as an entity that did not meet the traditions of 
self-government in the Czech Republic and was abolished, and its powers were transferred to the districts and communities. Accordingly, the order of formation and the volume of powers of the local self-government bodies of the basic level have changed. First of all, communities have the right to elect municipal authorities and to conduct local referendums, to form and to manage the budget, to provide their own socio-economic, cultural and communal needs.

At this stage in the Czech Republic there was a system of territorial division:- parliament (House of Deputies and Senate), central government (government and ministries);

- district departments (district administration);

- Municipal Governance and Municipal Council of Representatives.

In 1997, the Czech Parliament approved a law on the two-level structure of the administrative division of the country, the actual implementation of the administrative-territorial system of the country took place only in 2000 after the adoption of laws on elections to local self-government bodies, determination of their status, powers and relations with local and central authorities.

As a result of the transformation of the administrative-territorial system from January 1, 2000, 14 regions (instead of 8 before the reform) were created as higher territorial units of self-government. In addition, on May 16, 2001, amendments were made to the Constitutional Law of 1997 "On the Establishment of High Territorial Self-Government Units and on the Changes of the Constitutional Law of the Czech Republic No. 1/1993» regarding changes in the names of the four regions. Consequently, the Czech Republic abandoned the three-level structure and returned to a twolevel structure.

By the Law No. 347/1997 of the provisions of Art. 99 of the Constitution of the Czech Republic were redefined and affirmed that the country is divided into municipalities, which are the main territorial self-governing units, and the provinces that are the highest self-governing units. Thus, the 14 regions that were formed replaced 80 district administrations. As a result of the reform, 6,242 communities were formed, which according to the Constitution of the Czech Republic (Article 100) are constituent parts of the territories.

The municipality in the Czech Republic has always been regarded as the main element of self-government. In accordance with Article 1 of the 
Law "On Communities" of April 12, 2000, N6 128/2000, the municipality is the main territorial community of citizens, which forms a territorial unit that is bounded by the borders of the municipality. A municipality may acquire the status of a city if it has at least 3,000 inhabitants, and the chairman of the Chamber of Deputies will take such a decision. In addition, cities such as Kladno, Ceske Budejovice, Plzeň, Karlovy Vary, Usti nad Labem, Liberec, Hradec Krakow, Pardubice, Jiława, Brno, Zlín, Olomouc, Ostrava, Opava, Gavierow and Most received special status. The status of such cities (statutory) is determined by law and their charters. Management in the cities of Brno, Ostrava, Plzeň has its own peculiarities distinctive from other cities, in particular:

- the municipal authorities carry out, in addition to the powers of the municipal administration, in the respective territory, also the powers of the district administration, unless otherwise provided by law;

- the city manager appoints and dismisses the manager of the regional administration;

- in the event that the representative office is unable to meet within 6 months, the Ministry of Internal Affairs is entitled to dismiss it [9].

A municipality ruled by its elected representatives has, in full use of its capabilities, the duties and rights assigned to it, and also satisfies the needs of its citizens. Citizens, in their turn, have the right to exercise control over the activities of local self-government bodies, namely, the activities of the mayor and members of the Council.

Municipalities are the part of larger local government units and represent self-governing community of citizens governed by elected representatives of the population: the municipal council and the senior citizen. Members of the municipal council are elected by universal and equal election for 4 years. The condition for participation in the elections is the residence in the territory.

Local communities of the citizens can monitor local activities. Bodies of local self-government are independent, legal and economic entities. Bodies of local self-government have the right to decide on the following issues: to develop projects and approve municipal budgets, as well as reports on municipal activities; freely distribute funds among the relevant services in order to meet public needs; approve the composition of municipal enterprises and funds. Thus, it can be emphasized that the presence of a large number of small entities does not positively affect the implementation of the principles of effective local self-government. 
Municipalities can conduct administrative activities regardless of the state, which may interfere in the affairs of the territories only in case of violation of laws and only within the framework of legislative norms. Municipalities have the right to dispose of property and conduct economic affairs in accordance with their own budget (Article 101).

As a result, the administrative-territorial reform in the Czech Republic provided for the formation of a multi-level governance, inherent in the EU. This has enabled these countries to derive certain benefits from the EU structural policy and influence the process of implementing the EU's regional policy through the Committee of the Regions. But experience has shown that such municipalities are not capable of realizing self-government functions, since they do not have the appropriate material resources and the required number of specialists and officials. It is now clear that the decision-making process will be effective in combining small entities into large ones.

Municipalities provide for the solution of local issues independently within the framework of self-government or carry out delegated powers within the respective territories to the extent stipulated by special legislation. The spheres of self-activity of municipalities, which they carry out within certain territorial boundaries, include economic development, social security and cultural activities, environmental protection, as well as activities envisaged by special legislative acts [9; 1, p. 97].

At the local level there are 6242 municipalities.

The municipal councils include deputies elected by direct vote for a four-year period. The Council of Deputies elects members of the executive body - the Municipal Committee. Among them are the mayor and deputy mayors. This executive body forms the commission.

The mayor is elected by a council of its members for four years. He heads the Municipal Committee, Administration and Council. In municipalities where the Municipal Committee has fewer than 15 members, the executive power is represented only by the mayor.

Authority of the municipal council:

- municipal budget;

- local development;

- municipal police;

- water supply;

- agriculture; 
- primary education;

- housing;

- social assistance;

- urban planning.

The Regional Assembly consists of members elected by direct vote for a four-year term. This representative body controls the budget and subsidies that are provided to municipalities. He is also a subject of legislative initiative.

The executive body for the region's council is the Regional Committee, consisting of the president, vice-presidents and other members, who are elected for a four-year term. This committee assists at the level of regional governance and public services.

Authority for the region's council [10]:

- secondary education;

- roads;

- social assistance;

- environment protection;

- public transport;

- regional development;

- health care.

In the Czech Republic, as in most countries around, the contribution of own revenues to local budgets remained too small.

The rights of councils for establishing local taxes were not passed by law. In spite of this, associations of local authorities in many countries focused on ensuring the transfer of a fair share of national taxes to the local level. In the Czech Republic, municipalities receive 21 percent of the total personal income tax and corporate profit tax. The distribution is based on the population growth rate. This method of tax revenue distribution is fixed in the law (as in Slovakia) and does not depend on decisions regarding the State annual budget.

In the Czech Republic there is the Ministry of Regional Development, which was established in 1996. It has the task of ensuring that the policy of the Czech Republic is consistent with the policy of the European Union, which traditionally plays a significant role in the regions [4, p. 271].

The municipality's governing bodies are the municipalities (the highest self-governing body, which performs the most important powers in the area of self-government), the municipal council (executive body) and the municipal administration. 
Thus, local self-government in the Czech Republic is one of the main constitutional institutions that allows the population of self-governing territories, regardless of the state authorities, to resolve certain issues of local importance within the limits of their own and delegated competence, stipulated by the law of the republic.

An analysis of the Czech experience will allow Ukraine to avoid the standard political risks and negative consequences that may arise as a result of the imbalance between the forms of government and the failure to take into account the general trends in the establishment of democracy. At the same time, it will contribute to the borrowing of positive institutional changes, mechanisms for the implementation of the reform processes and the establishment of a functional civil society. It should also be taken into account that the reform of the local self-government system is a complex and long-term process, the effectiveness of which depends on the legislative provision of administrative reform and skilled administration.

In EU countries there are two-level (eg, municipality, district) or threelevel (village or parish, municipality, district) self-government model. In Ukraine, the situation is similar. There are three levels: village, town and city councils - district councils - regional councils. Plus, regional centers are also territorial communities.

To prove local self-government to the absolute, that is, to one level, does not seem expedient. The multi-level system, on the one hand, can bring power closer to specific citizens at the village or village level, and on the other hand, accumulate funds and staffing capacities at the district and oblast level (district, region) to provide more complex services to the population. It is clear that the rural community (or commune), especially in Ukraine, is not able to receive a significant amount of funds and attract high-quality specialists to implement complex infrastructure projects - the construction of a hospital, school, gas pipeline, etc.

\section{Conclusions}

After analyzing the current state of local self-government in such post-socialist countries as Slovenia and the Czech Republic, and after examining the latter, on the whole, positive conclusions, European experts, in particular representatives of the Congress of Local and Regional Authorities, we can state that the organization of local self-government in the Czech Republic meets the standards of the European Charter of Local Self-Government. 
Thus, foreign municipality knows various models and types of organization of local self-government. Differences in the construction of local self-government systems depend on many factors: the country's dominant political regime, the ideas of the organization of power and local governance, the state structure and the administrative-territorial division of the state, national traditions, etc. The analysis of the basic systems and models of local self-government, the characteristics of local governments of foreign countries allows us to borrow useful foreign experience for the modern Ukrainian reality, and also take into account the negative experience of the organization and functioning of the principles, functions and bodies of local self-government of the respective countries. Changes in the economy, politics and ideology of modern states call for the adaptation of existing systems of local self-government to new realities. In addition, the practice of municipality is constantly being improved, producing new models, forms, types of organization of local self-government. The process of reforming of local self-government is one of the most noticeable phenomena in the world community. Its general tendency is the development of self-governing principles and the decentralization of power, which simultaneously coincides with the statement of the growing inability of the state to resolve some of the issues of public life in centralized forms.

The achievement of the desired state of local self-government is impossible without the implementation of a number of legislative and institutional reforms. Such are the transformations concerning the administrative-territorial system, the election of local deputies, the formation of executive bodies of local self-government, the delegation of powers and control over their implementation, the collection of local taxes, the maintenance of unprofitable enterprises, etc. At the same time, the orientation of foreign experience in solving such problems and the fundamental values in the field of local self-government of the European Union countries should not be avoided.

The development of the system of local self-government through the reform can be considered as such that is ensured not only by external factors but also by internal mechanisms, as the development through the processes of self-organization. This development is primarily provided by the activity of the officials of local self-government. This happens in cases when, for example, an official, taking part in managerial decision-making, offers new and effective methods for their implementation. In this case, the official of local self-government is implementing an innovative type of behavior. In 
real conditions in the system of local self-government there are the processes of the development through the self-managed development and managed development.

The scientific literature on the management of innovations, deals with the problems of the development of the new qualitative approaches to the decision-making of innovative solutions, the creation of the strategic management systems. As for the historical perspective, it is necessary to point out that initially the problem of the development of systems have been studied in the connection with the problem of the development of enterprises, when developing the methodology of strategic management and planning. Ineffective functioning of enterprises in a dynamic, competitive environment that was associated with the inability to determine adequately the parameters of the environment and the immutability of functional structures of enterprises, was the beginning of the transition to the development and usage of methods of the strategic management.

Strategic planning includes the specific steps associated with the identification of the problems, strategic goals, the criterion of effectiveness of implementation of the strategy, and others. In this case, with the aim of expediting the system response on the external influence factors, some of the strategic powers, as a rule, should be referred to the heads of the main technological process (the managerial decision-making and service delivery). As you know, today advanced industrial corporations use flexible, organic structures to govern innovation processes. In the first stage of the innovation process (ideas, analysis and assessment, calculation of the budget) employees gather in informal, poorly regulated project teams (creative teams). And in the second stage (implementation of innovations) rigid, formalized organizational structures are used.

To improve the innovative climate in the system of local self-government, should be implemented the mechanisms of the innovation policy. It means that one of the directions of the development of the mechanisms of the management of the innovations (reforms) may be the creation of research groups on the development of policy of local self-government reform, the strategy of its development.

So, the main success factors for increasing the effectiveness of the development not only separate social institutions, but states, today, despite of the global crisis, become the paces of transition to the sustainable development and the usage of new knowledge in the system of local self-government, 
which includes the introduction of modern technologies and administrative methods, the development of modern competences of the officials of local self-government and so on.

It is necessary to open the way to a local initiative, to involve in the management of the affairs of their cities their inhabitants more actively - that is, to fill the real meaning of the concept of self-government. Local authorities, like the authorities of all other levels, should become open, transparent and understandable.

\section{References:}

1. Vidlakova O. (2001.) Polityko-administratyvni vidnosyny v Cheskii Respublitsi [Political-administrative relations in the Czech Republic] O. Vidlakov, Polityko-administratyvni vidnosyny: khto stoit u vlady? [Poditico-administrative relations: who is in power?] (ed). T. Verheine M., pp. 17-128.

2. Latsina K. (2000) Mistseve samovriaduvannia v Cheskii Respublitsi [Local Government in the Czech Republic], K. Latsina, Z. Vaidova, (Detsentralizatsiia: eksperymenty i reformy) [Decentralization: Experiments and Reforms] (ed) Tamasha M. Croat. - T.1. - Budapest, pp. 295-340.

3. Lemak V. (2003) Pravova reforma v Chekhii i Slovachchyni v umovakh postsotsialistychnoi modernizatsii: teoretychni i praktychni problemy [Legal reform in the Czech Republic and Slovakia in post-socialist modernization: theoretical and practical problems.] Dis ... doc. Jurid Science - K., pp. 414 - Mode of access: www.nbuv.gov.ua.

4. A.S. Prudnikov, L.A. Larina, M.V Maksutin (2007), Mistseve samovriaduvannia v zarubizhnykh krainakh: navch. posibnyk dlia studentiv BNZ, yaki navchaiutsia za spetsialnistiu "Yurisprudentsiia" [Local government in foreign countries: teach. A guide for undergraduate students studying in the jurisprudence] / under ed. AS Prudnikova - M.: UNIT1-DANA: the law of law, pp. 271.

5. Czech Republic [Electronic resource] // Wikipedia. URL: ttpi//ru.wikipedia. org/wiki/\%D7\%E5\%F5\%E8\%FF (revision date: 02.02.2018).

6. RozhodnutH bstavnHho soudu IleskG republic 35/1994 Sb. (PI 16 5/93; Svazekc 1; N61ezc 4; 35-40) - 19.1.1994*).

7. Usta Ceske republiky. Listina zakladnich prav a svobod // Uplne Zneni. $2003-138 .-$ s. $1-192$.

8. Zakoii “o obcich (obecni zrizeni)" ze dne 12. dubna 2000 roku, 1128 // Sbirka zakoiiu CR. - 2000 - 138-S. 1737-1764.

9. Zakon "o kiajich (krajske zrizeni)" ze dne 12. dubna 2000 roku, 1129 / / Sbirka zakonu CR. - 2000 - 138 - S. 1765-1782.

10. European Charter of Local Self-Government dated 15.10.1985, ratified dated July 15, 1997, No. 452/97 RP [Electronic resource]. - Mode of access: http://zakon2.rada.gov.ua/laws/show/994_036. 